\title{
Kamusal Alanın Yeni Yüzü Ekşi Sözlük Üzerinden Toplumsal Cinsiyet, iktidar ve Beden Analizi
}

\author{
Tuğba Metin Açer (Dr. Öğr. Üyesi) \\ Bolu Abant İzzet Baysal Üniversitesi Fen-Edebiyat Fakültesi \\ tugba.metin@ibu.edu.tr
}

Başvuru Tarihi: 05.11.2019

Yayına Kabul Tarihi: 02.05.2020

Yayınlanma Tarihi: 24.07.2020

https://doi.org/10.17680/erciyesiletisim.643315

\section{Öz}

İletişim teknolojilerinin gelişmesi toplumsal yaşamın bütün alanlarını köklü bir dönüşüm ile karşı karşıya getirmiştir. Geleneksel sözlük anlayışı da bu değişim ve dönüşüme ayak uydurmuş, e-sözlük anlayışı oldukça popülerlik kazanmıștır. Hatta önemli sosyal konuların, olayların, problemlerin bireyler tarafından fikirlerin sunulduğu ve tartışıldığı önemli bir platform haline gelmiştir. İletişim teknolojilerinin ve tüketim endüstrisinin getirdiği dönüşümlerden olan diğer alan ise "beden" ve "toplumsal cinsiyet"tir. Çağdaș kapitalist toplumlarda beden, tüketim endüstrisi tarafından şekillenen önemli bir tüketim alanıdır. Bu çalışmanın temel amacı; tüketim endüstrisinin dayattığı idealize edilen beden algısı üzerinden dayatılan hegemonik söylemlerin medya araçlarıyla nasıl yeniden üretildiğinin incelenmesidir. Öte yandan ideal beden algısının erkek ve kadına atfettiği rollerin ve yarattığı baskıların ortaya çıkarılması da bir diğer amaçtır. Günümüzde “yeni kamusal”lık olarak adlandırılan Ekş̧i Sözlük'te beden ile ilgili yapılan yorumlar araştırmanın kapsamını belirlemektedir. Ekşi Sözlük'te toplumsal cinsiyete ilişkin beden algısının izlenebileceği 6 başlık tespit edilmiş, iki tanesi ise amaçlı örneklem tekniği kullanılarak seçilmiştir. Bu çalışmada Ekşi Sözlük’te her ikisi de 2013 yılında açılan "Türk erkeği vücudu” ve "Türk kızı vücudu" başlıklarının altındaki Mart 2019'a kadar olan tartışma ve yorumlar analiz edilmiştir. "Türk erkeği vücudu" başlığı altına yapılan 240, "Türk kızı vücudu" başlığı altına yapılan 1080 yorum, eleştirel söylem analizi yöntemiyle değerlendirilmiştir. Eleștirel söylem analizi, dilde örtülü bir biçimde bulunan, ancak toplumdaki güç ve hiyerarşi ilişkilerini yeniden üreten söylemleri analiz etmede önemli bir yaklaşım biçimi olması açısından bu çalışmaya analitik bir perspektif sağlamıştır. Çalışmanın veri analiz aşamasında Nvivo 8 isimli nitel veri analiz programı kullanılarak yorumlar üç aşamada kodlanmış ve kategorilendirilmiştir. Yapılan nitel veri analizi sürecinin sonunda ise 5 tema ortaya çıkarılarak yorumlanmıştır. Sonuç olarak; hegemonik erkeklik ideal beden algısı üzerinden toplumda bir iktidar konumu olan sınıfsal değişkenler üzerinden yeniden üretilmektedir. Eril iktidarın yarattığı söylemler, kadın bedenini geleneksellik ile ilişkilendirerek küçümsemekte ve tahakkümünü yine hem beden hem de geleneksel toplumsal cinsiyet rolleri üzerinden yeniden kurmaktadır. Toplumsal cinsiyet ve sınıfın kesişimselliğinde ortaya çıkan eril tahakkümün, beden üzerinden farklı "kadın"lık ve "erkek"likleri hegemonik toplumsal cinsiyet rejimi içersinde hiyerarşik bir düzende konumlandırdığı söylenebilir. $\mathrm{Bu}$ çalıșma kapsamında ideoloji, güç/iktidar üzerinden temellenen eleştirel söylem analizi yöntemi, toplumsal cinsiyete ve bedene ilişkin söylemlerin örtük biçimde sınıfsal eşitsizlikleri de dilde barındırdığını ortaya çıkarmıştır.

Anahtar Kelimeler: Toplumsal Cinsiyet, Beden, İktidar. 
Research Article

\title{
Gender, Power and Body Analysis through Eksi Sozluk - The New Face of Public Space
}

\author{
Tuğba Metin Açer (Asst. Prof. Dr.) \\ Bolu Abant İzzet Baysal University Faculty of Arts \& Science \\ tugba.metin@ibu.edu.tr
}

Date Received: 05.11.2019

Date Accepted: 02.05.2020

Date Published: 24.07.2020

https://doi.org/10.17680/erciyesiletisim.643315

\begin{abstract}
The development of communication technologies has radically transformed all areas of social life. The traditional dictionary conception has also kept pace with this change and transformation, and the e-dictionary conception has gained quite popularity. It has become an important platform where vital social issues, events, problems are presented and discussed by individuals. Another area of transformation arising from communication technologies and the consumption industry is "body" and "gender." In contemporary capitalist societies, the body is a significant field of consumption shaped by the consumption industry. The primary purpose of this study is to examine how the hegemonic discourses imposed on the idealized body perception imposed by the consumer industry are reproduced through media.

On the other hand, its another aim is to reveal the roles and pressures posed by the ideal body perception to men and women. The comments made about the body in the "Ekși Sözlük," today, which is called the "new publicity," determine the scope of the research. There were six headings in the "Ekşi Sözlük," where gender perception of the body could be monitored, two of which were selected using the purposive sampling technique. In this study, the discussions and interpretations until March 2019 under the titles of the 'Turkish male body' and 'Turkish female body,' which were both opened in 2013, were analyzed. Critical discourse analysis was used to evaluate 240 comments under the title of 'Turkish male body,' and 1080 comments under the title of 'Turkish female body.' Critical discourse analysis has provided this study with an analytical perspective because it is an essential approach in analyzing discourses that are implicit in language but also reproduce the relationships of power and hierarchy in society. During the data analysis phase of the study, comments were encoded and categorized in three stages using the qualitative data analysis program called Nvivo 8. At the end of the qualitative data analysis process, five themes were revealed and interpreted. As a result, hegemonic masculinity is reproduced through class variables which is a position of power in society in terms of the ideal body perception. The discourse created by masculine power belittles the female body by associating it with traditionality and re-establishes its dominance over both the body and traditional gender roles. It can be said that male dominance, which emerges at the intersection of gender and class, positions different 'feminity' and 'masculinity' in terms of body in a hierarchical order within the hegemonic gender regime. Within the scope of this study, ideology and critical discourse analysis based on power/ruling revealed that discourse on gender and body implicitly contains class inequalities in language.
\end{abstract}

Keywords: Gender, Body, Power. 


\section{Giriş}

İnsanlık tarihine yön veren "merak" ve "anlamlandırma" duygusu, insanın hem doğayı hem de kendini anlamlandırma çabasını ortaya çıkarmıştır. Bu çaba sonucunda ruh ve beden ayrımı gibi düalist bir yaklaşım ortaya çıkmış, klasik felsefe geleneği ise bu ayrımda bedeni yalnızca ruhun bir taşıyıcısı olarak görerek, tarafını ruhtan yana belirlemiştir (Gülkaya Timurturkan, 2008, s.2). Bu düşünce Descartes ile daha baskın hale gelir. Descartes ruh ve beden arasındaki ikiliğin akıl ve beden arasında gözlemlendiğini, evrende tek varlık olan ve eylemleri kendi yasalarına göre düzenleyen Tanrı'nın, aslında akıl ile tanımlandığını belirtir (Bayraktar, 2010, s.63). 17. yüzyılda "aklın" keşfi ile aydınlanma düşüncesi, akıl ve beden ikiliği karşısında bedeni öteleyerek aklı ön plana çıkarmıştır. Düşünen, kontrol eden ve sorgulayan aklın aksine "beden" yalnızca bir kabuktur ve fiziki bir nesneden hiçbir farkı bulunmamaktadır (Nazlı, 2006, s.2). Aydınlanmanın kartezyan yapısı fenomenolojik yaklaşımın başı çektiği birçok postyapısalcı düşünür tarafından eleştirilmiş ve farklı disiplinler tarafından ele alınmaya başlamıştır (Gülkaya Timurturkan, 2008, s.2). Modern sonrası dönemde aklın karşında ikinci plana itilen beden artık doğal ve biyolojik değil, toplumsal olarak inşa edilmiş, ideoloji ve söylemlerin merkezinde bir olgu olarak görülmeye başlamıştır (Köse, 2011, s.76). Bedenler, kültürün dayattığı normlar çerçevesinde cinsiyet, yaş grubu, ekonomik konum için uygun olarak tanımlanan giyinme, bakım ve temizlik kuralları, güzellik ve çirkinlik kriterleri gibi ölçütler ile tanımlanır (Kara, 2011, s.24). Dolayısıyla bedenin, uzun bir süre aydınlanma döneminin baskın paradigması olan pozitivizmin egemenliğinde olan sosyoloji tarafından araștırma nesnesi haline gelmesi görece yeni bir olgudur.

Batı düşüncesinin temel aldığı kartezyan düşünceye dayanan akıl-beden ikiliğinin eleştirisi, bedenin yalnızca biyolojik bir süreç olmadığı ve sosyal tarafının da olduğu gerçeğinin kabulünü ortaya çıkarmıştır (Kara, 2011, s.25). Özellikle 1980'li yıllardan itibaren "beden" olgusu postmodern tüketim kültürünün ve iletişim araçlarının gelişimiyle birlikte yeni toplumsal ilişkiler ağı içerisinde ele alınmaya başlanmıştır. Çünkü beden, postmodern tüketim kültüründe "idealize" edilerek, tüketime koşut olarak artı değer kazanan yeni iktidar ve güç ilişkilerinin merkezindeki bir unsur haline gelmektedir. Filmler, reklamlar, diziler, geçtiğimiz son 10 yıla ise sosyal medya (facebook, instagram, twitter) üzerinden sunulan, "ideal beden" algısı, yeni "kadınlık" ve "erkeklik" anlayışlarını ortaya çıkarmıştır. Sağlıklı olma mottosu çerçevesinde sunulan spor yapmanın gerekliliği vurgusu, kitle iletişim araçlarıyla birlikte hızla yayılmaktadır. Medyada sıkça yer almaya başlayan "kaslı erkek"ler idealize edilen ve sunulan yeni erkek kimliğini vermektedir. Kendilerine dayatılan bu kimliği giyme zorunluluğunu hissedenler kendilerini spor salonlarında, protein tozu içerken bulmaktadır. Ancak toplumsal bir inşa olarak ele aldığımızda bedeni, toplumsal ilişkiler çerçevesinde değerlendirmek gerekmektedir. Toplumsal cinsiyet ilişkileri çerçevesinde "beden" algısına Ekşi Sözlük yazarları tarafından yapılan yorumlar çerçevesinde bakılan bu çalışmada, toplumsal güç ilişkilerinin merkezindeki bir olgu olarak "beden algısı" ele alınmıștır.

\section{Kuramsal Çerçeve: Sosyal Yönü Olan Bedenin Güç ve Tahakküm İlişkileri Çerçevesinde Ele Alınması}

Bedenin sosyolojik araştırmalara konu olması ise küreselleșen tüketim endüstrisi ile birlikte ele alınmaya başlayan yeni bir durumdur. Sosyologlar insan bedenini toplumsal ve kültürel bağlamı içerisinde anlamaya çalışmaktadırlar."The Body and Society" adlı eserinde Turner, beden sosyolojisinin dört temel ilkesini şöyle açlklar (Turner'dan aktaran Kara, 2011, s.28): 
1. Beden doğa ve kültürün kesişme noktasıdır.

2. Beden üzerinde kurulan güç ilişkileri grup cinselliğinde kendini belli eder.

3. Toplum, sosyal üretimi bireylerin özgür iradesine bırakmaz. Bu otorite temelinde bedeni siyasal olarak düşünebiliriz.

4. Beden siyasi iktidar mücadelelerin arenasıdır.

Sosyolojik açıdan insan bedeni toplumsal sınırlara ve eğilimlere koşut olarak şekillenen, yapılandırılmış bir toplumsal gerçekliktir (Cirhinlioğlu \& Cirhinlioğlu, 2011, s.403). Sınıf, toplumsal cinsiyet gibi sosyal değişkenler ile ilişkisi bağlamında ele alınan beden olgusu, sembolik olarak önem taşımaktadır (Öztürk, 2012, s.39). Bedeni sosyal ve kültürel bağlamı çerçevesinde inceleyen sosyologlardan birisi Fransız kültür sosyoloğu Pierre Bourdieu'dur. Bedenin güç ve tahakküm ilişkilerinin oluşturduğu alanda inceleyen Bourdieu'ya göre itaat aslında "toplumsal tahakküm ilişkilerinin bedensileșmesi"dir (Köse, 2011). Bu doğrultuda beden sınıfsal farklılık, beğeni, simgesel güç ve cinsiyetçi söylemler içeren dilsel beden kodlamaları yönüyle ele alınır (Köse, 2011, s.175). Bourdieu'nun teorisinde beden, bireylerin kültürel ve ekonomik sermayesinin bir gösterge alanı, simgesel gücün kaynağıdır.

Küreselleşmenin dayattığı yeni beden algısı cinsel olarak kışkırtıcı, başkalarının gözünden değer biçilen, biçilen değer karşısında ise kusurlu yanları düzeltilmeye çalışılan, dolayısıyla nesneleşen ve bireyin yegane sermayesi haline gelmiştir (Kızılçelik, 2003, s.90). Tüketim toplumunda fetișist bir hal beden, bu haliyle Köse (2011, s.27)'ye göre toplumsal bir itibar aracı haline gelerek simgesel sermayeye dönüşmüștür. Sağlıklı, bakıml, temiz, güzel, fit bir bedene sahip olmak belirli bir gelir ve refah düzeyi ile doğrudan ilişkilidir. Bu yönüyle simgesel güce sahip olanlar tarafından bir norm olarak sunulan "idealize edilen" bedene sahip olmanın karşılığı "üstün" bir gruba aidiyet hissi ile ödüllendirilmektir (Goldenberg, 2010, s.236).

Bedenin sembolik olarak taşıdığı en önemli alan toplumsal cinsiyet düzenidir. Cinsiyet gruplarına atfedilen kodlar ve farklılıklar, toplumsal cinsiyet düzenin hiyerarşik bir biçimde yapılanmasında belirleyici bir faktördür (Öztürk, 2012, s.39). Toplumsal dünya tarafından cinsiyetlendirilmiş bir gerçeklik olarak inşa edilen beden, yine cinsiyetlendirici görüşlere göre sosyal dünyayı kategorize eder (Bourdieu, 2018, s.22). Erkeklere evrensel olarak atfedilen üstünlük gücünü habituslara içkin halde bulunan şemalardan almaktadır. Biyolojik üreme ile toplumsal yeniden üretime ilişkin erkek merkezli temsili gösteren sembolik düzendeki kurucu karşıtlıklarda gözlenen ve işlevsel olan düşünme şemalarını, kadınların kendileri de uygulamaya koyarlar (Bourdieu, 2018, s.49). Sembolik şiddet kavramsallaştırması da işte hükmedilenin tahakküm ilișkilerine hükmeden tarafından oluşturulmuş kategoriler aracılığıyla bakması ve bu kategorilerin doğallaştırılıp içselleştirilmesidir (Bourdieu, 2018, s.50). Eril tahakküm, erkeklerin kadınlar üzerindeki tahakkümünün toplumsal cinsiyetçi söylemler vasıtasıyla eril ve dişil bedenlerin kurulumunu toplumsal açıdan anlamak için önemli bir yaklaşımdır.

Kadınlar sürekli başkalarının gözetiminde olmaları sebebiyle "gerçek beden" ile "ideal beden" arasındaki çelişkiyi sürekli deneyimlemektedirler (Bourdieu, 2018, s.88). Tüketim toplumunda "idealize" edilen beden algısı, kadını ince bel, kozmetik kullanılarak bakımlı olmak, giyim-kuşamda modayı takip etmek üzerinden motive ederken, erkekleri gücün sembolik olan kaslı ve atletik vücuda olmak üzerinden motive etmektedir. Bourdieu'ya göre toplumsal yaşamın tüm alanında baskın olan eril tahakküm bedene de müdahale ederek kadınların sembolik yabancılaşmasına sebep olmaktadır (Kaplan, 2017, s.1831). 
Sembolik yabancılaşmanın en ileri düzeyde yaşandığı kesim ise toplumsal uzamdaki konumları nedeniyle küçük burjuvazidedir (Bourdieu, 2018, s.88). Kadınların iktidar elde etme çabası ise double bind (Çifte bağ, çifte zincir) durumu yaratır. Buna göre kadınlar erkek gibi davranırlarsa, "kadınsılık" özeliklerini kaybedebilir, bu da erkeklerin iktidar konumlarını sorgulama haklarının kaybına neden olur; buna karşılık kadın gibi davranırlarsa da nitelikli ve uygun değilmiş gibi algılanırlar (Bourdieu, 2018, s.89). Kadınlardan beklenen bu çelişkili durum ise tüketim endüstrisinin sunduğu sembolik mallar piyasasından hem hoşa gitmek için ellerinde geleni yapmaya hem de karşı koymaya sevk edilirler (Bourdieu, 2018, s. 89). Kadınlar kendi bedenlerine yönelik yetersizlik hissini azaltmak için erkeklerin ve tüketim endüstrisinin onlara sunacağ aldatmacaları peşinen kabul etmektedir (Bourdieu, 2018, s.90). Bourdienun beden kavramsallaştırmasında itaat ve tahakküm ilişkilerinin kurulmasında toplumsal cinsiyetçi söylemler oldukça önemlidir (Köse, 2016).

Günümüzde eril bedenin erilleştirilmesi ve dişil bedenin dişilleştirilmesi her zamankinden daha fazla harekete geçirilmeye çalışılır ve tahakküm ilişkilerinin bedenselleşerek, doğallaştırılır (Bourdieu, 2018, s.75). Öyle ki fiziksel görünümün kișiye sağladığı fayda ve önem, kişinin yeteneklerinden ve çabayla elde edilecek taktirden daha önemlidir. (Köse, 2016, s. 177). Bu noktada ise Bourdieu'nun "bedene dönüşmüş toplumsallık" olarak adlandırdığı habitus kavramı devreye girmektedir. (Köse, 2016, s.178). Köse (2016, s.178) ye göre Bourdieu'nun habitus ile ima ettiği şey aslında toplumsal olanın pratik anlamının bedende somutlaşmasıdır. Bir iktidar alanı olarak beden, biyolojik varlığının ötesinde sosyal bir inşadır. Bu sosyal inşa süreci, toplumsal cinsiyet düzenine göre ayrımlaşan erkek ve kadın bedenine yönelik söylemler ile bireylerin kimliğinin oluşumunda etkin bir rol oynamaktadır. Kültürel olarak inşa edilen ve egemen kılınan ideal erkek ve kadın bedeni diğer bedenlerin buna uygun olup olmadıklarını ölçmek maksadıyla kullanılmaktadır (Öztürk, 2012, s.46).

Günümüzde ideal "erkek" ve "kadın" bedeninin sunumunda popüler kültür ve medya ürünleri önemli bir rol oynamaktadır. Bu çalışmada kadınlığın ve erkekliğin ölçümünde kullanılan idealleştirilmiş beden algısının bireylerin söylemlerine nasıl yansıdığı Ekşi Sözlük'te açılan "Türk kızı vücudu" ve "Türk erkeği vücudu" başlıkları altında yapılan yazarların yorumları üzerinden analiz edilmiştir.

\section{Metodoloji: Eleştirel Söylem Analizi ile Toplumsal Cinsiyet ve İktidar İlişkisinin Analizi}

Türkçe'deki karşılığı "söylem" olan "discourse" kavramı, toplumun sosyal ve düşüncel hayatını devam ettirmede kullanılan dil manasına gelmektedir (İrfan Erdoğan, 2014, s.287). Söylem, belirli kurallar, terminoloji ve konuşmalardan meydana gelen sistematik dilsel düzenleri tasvir etmek için kullanılan bir kavramsal içeriğe sahiptir (Tonkiss'ten aktaran Çelik \& Halil, 2008, s.100). Söyleme ilişkin kuram ve metodolojik yaklaşımların temelinde dilin gerçek dünyayı tam anlamıyla yansıtmadığı ve anlamın kültür içinde bağlam kazandığı varsayımına dayanan Ferdinand de Sassure'un lingiustik yaklaşımı bulunmaktadır (Çomu \& Halaiqa, 2015, s.44). Moderniteye yöneltilen eleştiriler sonucu post-modernistlerin ortaya koyduğu "gerçekliğin" anlam ve kültür dünyası tarafından oluşturulan söylem tarafından inşa edildiği düşüncesi, tek bir gerçekliğin değil çoklu "gerçeklik"ler dünyasının olduğu varsayımına dayanmakta ve söylemi merkeze çekmektedir (Oğuz, 2008, s.53). Sosyal bilim araştırmalarında nitel araştırma geleneği içerisinde değerlendirilen söylem analizi yöntemi dilin kullanımını, araştırdığı toplumun sosyal ve kültürel bağlamı içerisinde analiz eden bir yaklaşımdır. 
Söylem analizi yaklaşımları; eleştirel ve eleştirel olmayan yaklaşımlar olmak üzere ikiye ayrılmaktadır (Mora, 2008, s.10). Eleştirel olmayan yaklaşım; söylemleri betimleyici ve açıklayıcı tarzda analiz ederken, eleştirel söylem analizi yöntemi; söylemi betimlemenin ve açıklamanın yanı sıra söylemin güç/iktidar ve ideoloji tarafından nasıl gündelik yaşamda yapılandırıldığını, toplumsal kimlik, ilişkiler ve kültür bağlamında ne derece etkili olduğunu ortaya koymaktadır (Mora, 2008, s.10). Eleştirel yaklaşımların odağında "ideoloji" kavramı yer almaktadır. Buna göre eleştirel yaklaşımlar, toplumsal gücün dilsel pratikler vasıtasıyla meydana geldiğini ve bu güç ilişkileri dil içinde kodlanarak, yine dil vasıtasıyla dolaşıma girdiğini iddia etmektedirler (Karaduman, 2017, s.34). 1990’lı yıllardan itibaren popülaritesini arttıran eleștirel söylem analizi yöntemi bașta medya söylemleri olmak üzere, etnisite, toplumsal cinsiyet ve kimlik politikaları gibi alanlarda egemen söylemleri analiz etmek için kullanılmaktadır (Yerlikaya, 2019, s.195).

Grupların mensupları olarak konuştuğumuzda söylemlerimiz ideolojik temelli fikirlerimizdir aslında. Söz konusu ideolojik fikirleri ailede, arkadaş gruplarında onları dinleyerek ve okuyarak öğrenmeye başlar, sonrasında ise konuşma ve metinlerden televizyon izleyerek, okulda okutulan kitaplardan, gazetelerden, romanlardan, reklamlardan öğrenmeye devam ederiz (Van Dijk, 2015, s.19). Gündelik yaşamda ise bu ideolojik fikirler çerçevesinde bireyler toplumsal edimleri yerine getirirler. Bu noktada Van Dijk (2015, s.41), toplumsal analizin makro ve mikro düzeyinin söylem analizi üzerinden nasıl birleştirilebileceğini şu şekilde açıklar:

\footnotetext{
İdeolojilerin toplumsal tanıtımlarına grupların ve grup ilişkilerinin soyut makro düzeylerinden başlamak yerine, (gelin) ideolojilerin kendilerini aslında, yani gündelik yaşamın toplumsal pratiklerinde, yani çeşitli etkileşim biçimlerinde katılanlar olarak toplumsal aktörler arasında, nasıl ortaya koyduklarına tanık olabileceğimiz mikro düzeyde başlayalım. Bu günlük etkileşimin hem monolog metni hem de karşılıklı konuşma olarak son derece önemli bir biçimi söylemdir.
}

Van Dijk (2015, s.45)'e göre gündelik edimlerimiz ve etkileşimlerimiz ideolojiler tarafından güdülenir. Örneğin; birbiri ile etkileşen kadın ve erkeklerin cinsiyet ayrımcılığı gibi ideoloji ortaya koyması, zengin ve fakirler arasındaki etkileşimin sınıf ideolojisini ortaya koyması, farklı etnik gruptan kişilerin etkileşiminin etnik ayrımcılığı ya da ırkçılık karşıtı ideolojileri ortaya koyması gibi bir çok ideoloji gündelik edimlerimize motivasyon sağlar. Yani toplumsal bir grubun üyesi olarak davranır davranmaz insanlar ideolojilerini eyleme ve etkileşime taşıyabilirler (Van Dijk, 2015, s.41). Bu doğrultuda söylemler ideolojik bir içeriğe sahiptir ve söylem analizi de işte bu söylemlerimizde gömülü bir halde bulunan güç, iktidar ve hiyerarşik ilişkileri ortaya çıkarmaya yarayan analitik bir yöntemdir. "Biz" ve "onlar" ikiliği temelinde bireylerin birbirlerini karşıt olarak tanıtmalarının çıkış noktasını oluşturduğu söylem çalışmaları; politik, sosyal ve tarihsel bağlamı dikkate alarak, biz ve onlara ilişkin olumlu, olumsuz görüşleri, ima edilen bilgileri ve karşıt kamplara bölünen grupların görüşlerini vurgulayan sözcük seçimi ve söz dizimsel yapının analiz edilmesini sağlamaktadır (Van Dijk'ten aktaran Ülkü, 2004, s.376)

Söylem, grup aidiyetini ve dolayısıyla gruplar arasındaki ilişkileri bir yandan yansıtırken bir yandan yeniden inşa eder. Bir toplumsal grubun üyesi olarak "öteki"ni eleştirmenin gerekçesi birbirini tamamlayan iki stratejiyi içerir: birincisi kendi grubuna yönelik olumlu bir gösterim, ikincisi ise ötekinin olumsuz gösterimi (Van Dijk, 1993, s.265; 2015). Söylem analizinin tek bir yolu olmadığını belirten Van Dijk, buna karşılık söylem analizi esnasında şu noktalara dikkat edilmesi gerektiğini belirtir (Alp, 2016, s.157): 
- Söylemin tarihsel, kültürel ve sosyal bağlamını incelemek,

- "Biz" ve "onlar" hakkındaki olumlu ve olumsuz tutum ve görüşleri ortaya çıkarmak,

- Önvarsayımları ve ima edilenleri ortaya çıkarmak,

- Hangi grupların, iktidar ilişkilerinin ve çatışmaların bulunduğunu çözümlemek,

- Kutuplaştırılmış grup kanaatlerini yansıtan bütün biçimsel yapıyı incelemek.

İdeolojiler konuştuğumuz, yazdığımız ve yaptığımız şeyleri denetler, kontrol altına alır (Van Dijk, 2015, s. 39). Dolayısıyla belli bir ideoloji üzerine temellenen söylemler aslında güç ve iktidar ilişkilerinin açığı çıkarılmasında işlevsel bir özellik göstermektedir.

\section{Araştırmanın Kapsamı ve Örneklem Seçimi}

Toplumsal pratiklerimiz ve edimlerimiz ideolojiler tarafından empoze edilmektedir (Van Dijk, 2015, s.41). Sosyal yaşamda kadın ve erkekler cinsiyet ayrımcılığı veya feminizm gibi farklı cinsiyet ideolojileri ortaya koyabilmektedirler (Van Dijk, 2015, s.41). Bu çalışma ataerkil ideolojinin kurumsallaşmasında, tarihsel, sosyal ve toplumsal bağlamda yeniden oluşan formasyonunda "idealize edilen beden" üzerinden şekillenen söylemlerin toplumsal cinsiyet ilişkilerini yeniden yapılandırdığı varsayımı üzerinden şekillenmiştir. Öyle ki ataerkil ideolojinin kurumsallaşmasında ve yeniden üretiminde söylem merkezi bir konumdadır. Günümüzde toplumdaki yerleşik kültürel ve sosyal söylemlerin izlendiği, yeniden üretildiği alanlardan biri de e-sözlük platformudur.

İnternette faaliyet gösteren e-sözlük'ler içerisinde en popüler olan ve kendine ait bir alt kültür oluşturan site ise Ekşi Sözlük'tür (Gürel \& Yakın, 2007). Ekşi Sözlük'ün en önemli özelliği Türkiye'de katılımcılık esasına, yani üyeyazarların katkılarıyla devamlı güncellenen ve gelișen bir platform olan ilk sözlük olmasıdır (Yazıcı, 2016, s.124). Yorumların sürekli güncellenmesi, toplumsal değişim ve dönüşüm süreçlerinin gözlemlenebilmesi açısından da işlevsel bir özellik sunmaktadır. Kısacası, Ekşi Sözlük platformu kendine ait bir alt kültür oluşturan, yazarların yorumlarıyla sürekli güncellenen, popüler ve en çok takip edilen site olması sebebiyle bu araştırmanın kapsamını belirlemiştir. Ekşsi Sözlük bireylere özgürce, gerçek kimliklerini ifşa etme gereği duymadan dolayısıyla rahatça belirli bir olgu, olay, konu, durum, haber hakkında yorum yapma olanağı sunan alternatif bir kamusal alandır. Günümüzde bedene ve toplumsal cinsiyete ilişkin söylemlerin ortaya çıkardığı iktidar ilişkilerini ortaya çıkarmak üzere araştırma kapsamını oluşturan Ekşi Sözlük üzerinde tespit edilen 6 başlık içerisinden araştırmanın sorunsalı ve amacı çerçevesinde "Türk erkeği vücudu” ve "Türk kızı vücudu” başlıkları amaçlı örneklem tekniği doğrultusunda seçilmiştir.

Elbette çalışma kapsamının yalnızca Ekşi Sözlük platformu tarafından sınırlanmasının kısıtlılıkları bulunmaktadır. Farklı platformlarda yapılacak karşılıklı araştırmalara ihtiyaç duyulmaktadır. Ayrıca araştırma verilerinin yalnızca Ekşi Sözlük yazarlarının yorumlarının analizine dayandığından dilbilgisi hatalarından, söylenmek istenenin bazen tam olarak irdelenememesinden, net olmayan (bulanık) ifadelerin yorumlanmaya çalışılmasından kaynaklı sınırlılıkları bulunmaktadır.

\section{Veri Toplama ve Veri Analiz Tekniği}

Her ikisi de 13 Mart 2013 yılında açlan "Türk erkeği vücudu” ve "Türk kızı vücudu" başlıklarının altındaki Mart 2019'a kadar olan tartışma ve yorumlar Teun Van Dijk'in eleştirel söylem analizi yöntemiyle çözümlenmiştir. Ekş̧i Sözlük yazarları tarafından "Türk erkeği vücudu" başlığı altına yapılan 240, “Türk kızı vücudu” başlığı altına yapılan 1080 yorum, toplumsal cinsiyet ideolojisinin bireylerin algı ve anlam dünyasında nasıl şekil 
bulduğu, günümüzde iletişim teknolojilerinin ve tüketim endüstrisinin gelişimine paralel olarak şekillenen ve idealize edilen "beden" anlayışı üzerinden analiz edilmiştir.

Verilerin analizinde NVivo 8 isimli nitel veri analiz programı kullanılmıştır. Başlık altındaki yorumlar programa üç aşamada kodlanmıştır (Baş \& Akturan, 2013:74): İlk aşamada kavramsal olarak birbirine benzeyen yorumlar gruplandırılmış, yani açık kodlama yapılmış; ikinci aşamada açık kodlama sonucu ortaya çıkan kategoriler ilişkilendirilerek aksiyal kodlama yapılmış; son aşamada ise kategoriler daha üst kategori yani temalar (tematik kodlama)altında yeniden düzenlenmiştir. Toplam 34 kategoride kodlama yapılmış, kategorilerin araştırmanın sorunsalı doğrultusunda birbiriyle ilişkilendirilmesi sonucu ise toplamda 5 tema ortaya çıkmıştır. Elde edilen veriler araștırmanın bulgular bölümünde tartışılan temaları (başlıklar altında ayrıntılı bir şekilde tartışılmıştır)belirlemiştir.

Tablo 1: Veri analizi sonucu ortaya çıkan temalar

\begin{tabular}{|c|c|c|}
\hline & “Türk Erkeği Vücudu” & “Türk Kızı Vücudu” \\
\hline \multirow{3}{*}{$\sum_{\text {峞 }}^{\frac{c}{5}}$} & $\begin{array}{l}\text { • Hegemonik erkekliğin "ideal beden” } \\
\text { algısı üzerinden inşaası }\end{array}$ & $\begin{array}{l}\text { • İdealleştirilen beden üzerinden } \\
\text { gelenekselliğin suçlanması: "Kezbanlık" }\end{array}$ \\
\hline & $\begin{array}{l}\text { • Hegemonik erkeklik idealinin "öteki”leri : } \\
\text { geleneksel ötekiler "Türk kadını "ve" öteki erkekler" }\end{array}$ & $\begin{array}{l}\text { - Sinıf ve toplumsal cinsiyetin } \\
\text { kesişiminde kadın olma hali }\end{array}$ \\
\hline & $\begin{array}{l}\text { - Orta sınıf değerleri üzerine inşa } \\
\text { edilen hegomonik erkeklik }\end{array}$ & \\
\hline
\end{tabular}

\section{Literatür Taraması}

Günümüzde postmodern dünyasında ideolojiler üzerinden üretilen söylemler kitle iletişim araçları ve popüler kültür ürünleriyle topluma aktarılmaktadır. Tüketim endüstrisinin bir meta olarak değer biçtiği beden, tüketimin arzusunun körüklendiği ve hegemonik söylemlerin işlev kazandığı en önemli alanlardan birisidir. Erkek egemen toplumsal yapıda kadınlık/erkeklik ölçütleri güçlü olan erkeğe göre belirlenmektedir. Hiyerarşik bir düzenleme sitemi olan toplumsal cinsiyet, erkeğe baskın bir güç atfederek, “öteki”leri yani kadınları ve ideal erkek tasarımına uygun olmayan diğer erkekleri bir düzen içerinde sıralar (Connell, 1998). İdealize edilen hegemonik erkeklik söyleminde ise fiziksel güce sahip olma durumuna hemen hemen tüm toplumlarda önem atfedilmektedir.

Literatürde yapılan çalışmalara bakıldığında hegemonik erkeklik söyleminin oluşmasında özellikle günümüzde popüler kültür ürünlerinin (reklamlar, dergiler, diziler, filmler vd.) dayattığı güçlü, sağlıklı, fit, kaslı, bakımlı erkek bedeni imgesinin oldukça etkili olduğu görülmektedir (İlker Erdoğan, 2013; Ertan, 2011; Öztürk, 2012; Seden Meral, 2011). Seden Meral (2011, s.309) erkek dergilerini analiz ettiği çalışmasında, ideal hale getirilen kaslı erkek vücudunun erkeğin gücünü, iktidarını ve hegemonyasını ötekilere ilan eden bir işleve sahip kılınmasının bir aracı olduğunu belirtir. Günümüzde cinsiyetlendirilmiş bir gerçeklik olarak inşa edilen ve sunulan beden algısı, eril ve dişil bedenleri kendi içerisinde hiyerarşik bir düzende sıralar. Örneğin, Men's Health adlı erkek sağlık derginin içerik analizini yapan İlker Erdoğan (2013, s.150), sağlıklı yemek yeme pratiğinin "kadınsı" olarak algılanmasına yönelik genel bir eğilimin olduğu toplumsal bağlamda, beslenme ile ilgili tıbbileştirilmiş bilgi sunan bu tür dergilerin hedef kitlesi için sağlıklı erkeği idealleştirirken, bir yandan olumsuz sağlı davranış ve tutumları ile ilişkili bir hegemonik erkeklik imajını yeniden ürettiğine dikkat çeker.

Kapitalizmin günümüzde baskın ideolojik söylemlerin, bireylerin algı ve anlam dünyasında dönüşümünü sağlayan bir diğer etkili alan ise küresel film endüstrisidir. Bireylerde 
tüketim algısını "sınıfsal üstüntünlük" sağlama yönünde güdüleyen filmler, bir yandan hakim ideolojileri yeniden üretirken bir yandan da karlarını maksimize etmektedirler. Hindistan'da Dhareshwar and Niranjana (1996) tarafından yapılan bir çalışmada kadınlık ve erkekliğin küresel film endüstrisi ile nasıl değișime uğradığı ele alınmıștır. Mani Ratnam'ın yönetmenliğini yaptı̆̆ı Roja ve Bombay gibi filmlerde üst kastta temsil edilen karakterlerin kot pantolon ve sneaker ayakkabı giymesi, gerçek yaşamda daha düşük kast mensubu erkeklerin giyim tarzını dönüşüme uğratmıştır (Dhareshwar \& Niranjana, 1996). Geleneksel ve kırsal giyim tarzını benimseyen gençler bu filmden sonra, üst kastın giyim tarzını bir norm olarak benimsemişlerdir (Dhareshwar \& Niranjana, 1996).

Toplumsal cinsiyet ve bedene ilişkin idealler zaman içerisinde dönüşüme uğramakta ve toplumsal cinsiyet hiyerarşisi içindeki güç ilişkilerini de dönüştürmektedir. Örneğin, bir erkeğin bakımlı olması kuaföre gitmesi, manikür ve cilt bakımı yaptırması bundan 30-40 öncesinde anormal bir durum olarak algılanır iken günümüzde maddi gücün ve prestijin bir göstergesi haline gelmiştir. Barber (2008) tarafından Amerika'nın Kuzey Kalifornia eyaletinde kişisel bakımları için kadın kuaförüne gitmeyi tercih eden 15 erkek ile derinlemesine görüşme yöntemiyle yapılan çalışmada erkekler tarafından hegemonik beyaz, orta sınıf, heteroseksüel erkek normlarının diğer erkeklikler karşısından nasıl yeniden üretildiğine odaklanmaktadır. Barber (2008, s.472) kadın kuaförüne gitme gibi feminen bir algı yaratacak eylemin ilginç bir şekilde erkekler tarafından kendi profesyonellikleri statüleri bağlamında ve sınıfsal bir zeminde beyaz işçi sınıfı erkekliği karşısından tanımladığına dikkat çeker. Kadınlar açısından da tüketim odaklı ideal kadın bedeni algısının kadınlar üzerinde yarattığı baskıyı ortaya koyan birçok çalışma mevcuttur (Dedeoğlu \& Savaşçı, 2005; Doğan, 2010). Örneğin, Doğan (2010, s.58) tarafından yapılan Balıkesir il merkezinde 422 kadın ile çalışmada tüketim kültürünün idealize ettiği kadın bedenine gerek sağlık, gerekse estetik açıdan kaygı duydukları ancak buna ulaşmak için tüketim davranışlarını aynı oranda sergileyemediklerini ortaya koymaktadır. Bu durum tüketim odaklı ideal beden algısına ulaşma yönündeki çabaların sınıfsal faktörlere göre değiştiğini göstermektedir.

\section{Bulgular}

\section{Ekşi Sözlük'te "Türk Erkeği Vücudu” ile İlgili Yapılan Yorumların Analizi}

Ekşi Sözlük yazarları tarafından yapılan "Türk erkeği vücudu" ile ilgili yorumlara bakıldığında, günümüzde bir iktidar unsuru haline gelen "ideal beden algısı" etrafında yapılan yorumlar dikkat çekicidir. Öyle ki "Türk erkeği vücudu” bu anlamda "öteki" ler ile karşılaștırma ve kıyaslama yolu ile ya yüceltilmekte ya da eleştirilmektedir. Yüceltme, “Türk erkeği vücudu”nun Türk kadınına oranla sportif olarak daha fit bir görünüme sahip olması gerekçe gösterilerek yapılmakta iken, -ki tahminen bu erkek yazarlar tarafından yapılmakta-, eleștiri ise bir diğer "öteki” Avrupalı erkekler ile kıyaslanarak yapılmaktadır. Her iki açıdan da bakıldığında, "Türk erkeği vücudu" başlığı altında yapılan yorumların tüketim endüstrisi ve küreselleşmenin dayattığı hegemonik erkekliği yeniden ürettiği söylenebilir.

\section{Hegemonik Erkekliğin “ỉdeal Beden” Algısı Üzerinden İnşaası}

Postmodern toplumlarda kimlik tüketim ile ilişkilendirilir. $\mathrm{Bu}$ doğrultuda kimlik süreç olarak değil dış görünüş, imaj, tüketim ve boş zaman etkinlikleri doğrultusunda oluşturulmaktadır (Kula Demir, 2016, s.81). Bedenin spor, diyet, sağlıklı beslenme, kozmetik ürünleri, estetik operasyonlar yoluyla ideal forma kavuşturma çabası günümüzde oldukça popülarite kazanmıștır. Bedene müdahale eden bu tür pratikler, 
belirli kimlikleri bedenlere empoze ederek, devlet ve medyanın yanı sira sosyal etkileşimde bulunulan diğerlerinin de kontrol alanı haline gelmektedir (Aktaran Öztürk, 2012, s. 43; Turner, 1992). Bireylere ürün ve hizmet satın alma yolu ile belirli bir yaşam tarzı ve kimlik vaad eden ve özellikle bedene yönelik pazarlama stratejileri, kimlikleri yeniden kurgulanan, dolayısıyla sabit olmayan bir süreç olarak sunmaktadır (Kula Demir, 2016, s.82). Günümüzde idealize edilen hegemonik erkeklik algısında kaslı olmak aslında yeniden kurgulanan bir durum olarak erkek kimliğinin doğal bir bileșeni haline gelmiştir:

“omuz genişletilebilir, bel inceltilebilir, göbek sıfırlanabilir. kalça sıkılaştırılabilir. bunlar genetik değil. ki artık eskiye oranla çok daha fazla fit erkek var. 19-20 yaşında çocuklar havuz başlarında adonisle geziyorlar. öyle açllk vücudu falan da değil. bildiğin define etmiş. (penchepathi)"

"benim boyum 181 ve 97 kiloyum. vücudum vin diesel gibi. ben mutluyum bu ölçülerimden, sporumu aksatmıyorum". (elalemin doktoru)

Toplumsal idealleri yansıtan medya, erkekleri tüketici bir kitle haline getirmek için, geleneksel erkek kimliğini dönüștürerek "metroseksüel erkek" kimliğini yaratmıștır (Kula Demir, 2016, s.82). Küresel film ve tüketim endüstrisi vasitasıyla üst sinıf tüketim normları tarafından idealize edilen beden algısı tüketim odaklı olarak empoze edilmektedir. Aşağıdaki yazarın ifadelerinde modern kıyafetlerin yakışma şartının ideal bedenden geçtiği görülmektedir:

"en pahalı tişörtü bile giyse yakışmaz. ayni durum bacak ve kalça kasları için de geçerlidir, giydikleri pantolonu bir turlu dolduramazlar, gerekli olan bütün girinti çıkıntılar belirsizdir, sanki toplama kampından dün kurtulmuş gibi bir görüntüleri vardır" (maviçorap)

Spor, boş zaman etkinliğinin ötesinde iktidar ilişkilerinin yeniden üretildiği bir alandır. $\mathrm{Bu}$ yönüyle spor hegemonik erkekliğin inşasını pekiştiren bir işleve sahiptir (Hacısoftaoğlu \& Koca, 2011, s.70; Talimciler, 2016). Spor, erkekliğin aktif, meydan okuyucu, güçlü, saldırgan, rekabetçi vb. olduğunu yeniden vurgulamak için erkeksilik mitlerini yeniden üreten bir formdur (Talimciler, 2016, s. 51-52). Așağıdaki yorumlara bakıldığında spor yapma etkinliğinin erkeklerin kadınlar üzerindeki önemli bir simgesel güç haline geldiği görülmektedir:

"gym için oran veriyorum 3 erkek 1 kadın. erkekler daha çok önem gösteriyorlar bu konuda." (mukan)

"onu bunu bilmem de 4 gyme gittim hepsinde erkek oranı minimum \%85 di. keșke kadınlarımızı da spor salonlarında görebilsek." (sultanofswing)

Connell (2019, s. 115)'a göre cinsiyeti ilgilendiren toplumsal ilişkiler bedensel performanslar aracılığı ile kurulur ve aynı zamanda simgesel bir hal alır. Spor alanı da hem erkekler arası rekabet ve hiyerarşiyi, hem de kadınların dışlanması ve tahakkümü gibi toplumsal ilişkileri içeren bir şekilde organize edilmiştir (Connell, 2019, s.115).

\section{Hegemonik Erkeklik İdealinin "Öteki”leri: Geleneksel Ötekiler "Türk Kadını" ve "Öteki Erkekler"}

Bourdieu'ya göre toplumsal cinsiyet birbirine karşıt ve birbirini tamamlayan temellere göre ayrışan, karmaşık ve sembolik bir düzen biçiminde varlığını sürdürmektedir (Öztürk, 2012, s.42). Buna göre sembolik düzen içerisinde kadın ve erkeğe biçilen rol ve pratikler, kadın ve erkeğe ilişkin bedensel farklıklarda da kendini göstermektedir. "Kadınsı"lık ve "erkeksi"lik üzerine söylemler, bireyin kimliğini bedeni aracılığı ile belirleyen "erkeklik" ve "kadın"lığın sosyal inşasıdır (Öztürk, 2012, s.43). Ekşi Sözlük’te "Türk erkeği vücudu" ile ilgili yorumlara bakıldığında kadın ve erkek karşıtlığının bedene yönelik söylemlerde sosyal olarak nasıl inşa edildiği görülmektedir: 
"son zamanlarda yalandan da gidilse spor salonları revaçta olunca türk kadınlarına oranla durumu çok daha iyidir. kadınların durumu ise hakikaten facia durumda." (cey30)

"türk kadını vücudu ile benzer özellikler gösterir genel olarak. ancak oranlarsanız türk kadınına göre daha fittir". (vadideki diken)

Türk erkeği bedenin Türk kadını karşısında yüceltilmesinin en sık öne sürülen gerekçesi, özellikle sosyal medya ve popüler kültür ürünleri tarafından dayatılan spor yaparak kaslı ve fit vücuda sahip olması gerekliliğidir. Beden ve erkeklik arasındaki ilişkiyi irdeleyen araştırmacılardan olan Connell (2019, s.99)'a göre "gerçek erkeklik" erkeklerin bedenleriyle ilgilidir. Kültürel bağlama göre şekillenen "hegemonik erkeklik" diğer erkeklikleri kategorize eden bir niteliğe sahiptir. Bu kavram, farklı erkeklik ve kadınlık halleri arasındaki hiyerarşiyi ve bunlar arasındaki güç ilişkisini göstermektedir (Baştürk Akça \& Tönel, 2011, s.28).

"tahminimce artık erkeklerin \%40'ı spor yapıyordur, yapmayanların da çoğunun hayatında bir dönem muhakkak sporla geçmiștir. (en kötü mahallede orta gol oynamıștır). spor yapan kadınlarımız da maalesef sporu yaz öncesi meşgale olarak görüyorlar. "yaza girerken az ye, bol kardiyo yap zayıfla yaza hazırsin" mottoları var." (vadiden diken)

Erkek bedeni, kadın bedenini tanımlarken bir ölçüt olarak kabul edilmektedir. Daha iyi ve daha kötü skalasında daha kötü kabul edilen kadın bedeni, geleneksellikle ilişkilendirilerek eleştirilmektedir. Örneğin, aşağıdaki sözlük yazarlarının ifadelerine bakıldığında, kadınları sosyal yaşamda sınırlayan normların ve kültürel yaptırımların yarattığı durum yine beden ve yaşam tarzı eleştirisi üzerinden kadınlara mal edilmektedir. Geleneksel beslenme tarzı, boş zaman faaliyetleri, evlilik, çocuk doğurma, güzellik ve bakım ölçütlerine uymama gibi sebepler gerekçe gösterilerek ideal beden algısından saptığı belirtilen kadınların hegemonik erkek ideali karşısında küçümsendiği görülmektedir:

“... hamilelikten sonra 500 kilo olup ömrünün kalanını duba olarak geçiren türk kadınına fazladır." (kafamdanokta1)

"beslenme ş̧ekliniz desen, bütün gün kek, börek, tatlı. akşam yan gelip yatayım, dizi-film izleyeyim, oh. biraz genetik şansı olan varsa fiziksel anlamda idare ediyor (o da evlenene, çocuk doğurana kadar) ..." (mulumbu)

Özellikle 1990'lı yılların sonlarından itibaren erkek bedeni reklamlarda, dergi kapaklarında, dizilerde, filmlerde ve diğer popüler kültür ürünlerinde sıklıkla kullanılmaya ve tüketim toplumunda erkeklerin birer tüketici olarak konumları dikkat çekmeye başlamıştır. Giysi, tıraş köpügüu, parfüm ya da otomobil gibi ürünlerin pazarlanmasında erkek bedenin kullanımı, kadına ait bir özellik olan "güzellik" kavramı etrafında değerlendirilmesine neden olmuştur. Kaslı ve bakımlı erkek figürlerinin popüler kültür ürünlerindeki sunumu "ideal beden" algısında değişimleri de beraberinde getirmiştir. $\mathrm{Bu}$ sebeple erkek bedenini kadına göre değerlendirmekten ziyade, hegemonik erkeklik değer ve normlarının söz konusu toplumsal dönüşümler çerçevesinde hegemonik yapıyı muhafaza eden bir şekilde yeniden üretiliyor olmasından bahsetmek daha uygundur (Öztürk, 2012, s.47). Öyle ki yorumlardan da görüleceği üzere "Türk erkeği vücudu" ile ilgili eleştirilerde bile (yorumları yapanların bir kısmının kadın olduğu tahmin edilmekte) geleneksellik karşısında ideal beden algısı yoluyla kurulan hegemonik yapının nasıl yeniden üretildiği görülmektedir: 
"genel ortalaması 1.75 civarındadır. kare tiplidir. dar omuzludur. göğüs genellikle kıllıdır. kaslı kolları olsa da kaslı bir göbek falan görmek çok enderdir. kötü bir gülümseyişleri vardır. ağız bakımları genellikle kötüdür."( kirazmevsimi )

"3 km yol yürümeye dayanamayacak bacak kasları, 15 kg yükü 2 km taşıyamayacak kol kasları, bel ağrısını engelleyemeyecek karın kasları, dik yürümesini sağlayamayacak karın ve boyun kasları, pantolonun/şortun kemersiz belinde durmasını sağlayamayacak, oturmaktan düzleşmiş ... ile hazır beslenme sonucu katmanlaşmış bölgesel yağ birikintileri ile şekillenmiş vücuttur. "(madarch)

Geleneksel Türk erkeği vücudu karşısında inşa edilen ideal erkek bedeni, diğer erkekleri yani aslında "biz" gibi olanların bedenini ölçmek için bir araçtır. Yani geleneksellik karşısında idealize edilen "hegemonik erkek bedeni" ise, diğer erkek ve kadın bedenlerini kategorize etmekte bir ölçüt haline gelmektedir:

"her maçını izlediğimde, ülkenin \%50'sinin vücudu bu adam gibi diyorum. Çıkart formayı üstünden, giydir adama çizgili pijama-beyaz atlet, koy mangalın başına; hepinizin dayısındanamcasindan farkl olmayan bir adam"(spb)

Erkek bedenine yönelik eleştiriler çoğu zaman "öteki” ile kıyaslama yoluyla yapılmaktadır. Bu doğrultuda yazarların ifadelerine bakıldığında Avrupalı erkeklerin vücutları "idealize" edilerek Türk erkeği vücudunun eleștirildiği görülmektedir:

\footnotetext{
"türk erkeği vücudundan çok Türk insanı olarak ele almak daha doğru olacaktır. sokakta güzel bir kız ya da yakışıklı erkeğe rastlama oranı çok düşüktür. bakımsız olmak, kötü giyim, biçimsiz vücut, kısa boy, gereksiz özgüven, kötü iletişim bir araya gelince gerçekten çirkin bir insan profili ortaya çıkıyor. hem fiziken, hem ruhen. slav ırkı ve nordic insanları fena tokatlar." (psikopatik tikli sazanik fok)

"son yillarda spor yapan erkeklerin çoğalmasıyla avrupa erkekleriyle arasındaki makas daralmaktadır. biraz da bakımlı olunca yakın bir gelecekte pick up the girls in europe moduna gireceklerinden emimim "(saylıkubac)
}

Kimliğe yönelik yaklaşımlarda da ele alındığı üzere, birey tarafından benlik "öteki" karşısında, "biz" ve "öteki”"nin farklılıkları temelinde inşa edilmektedir (Connolly, 1995, s.92-93). İdealize edilen erkek bedeni aslında bir "öteki” olarak Avrupalı erkeklerdir.

\section{Orta Sınıf Değerleri Üzerine İnşa Edilen Hemegomonik Erkeklik}

Toplumsal güç ilişkilerinin oluşumunda para/servet ve sınıfsal konum önemli iktidar unsurudur. Toplumsal cinsiyetin önemli bir bileşeni olan erkeklik de, toplumsal süreçte toplumsal güç ilişkilerinin ve toplumsal yapının öteki unsurlarıyla etkileşim halinde bulunmaktadır (Demez, 2011, s.325). Bedeni bireyin sosyal konumuyla ilișkisi çerçevesinde ele alan Bourdieu'ya göre bedenin gelişimini sağlayan sınıf temelli nesnel koşullar önemli bir belirleyicidir (Bourdieu'dan aktaran Öztürk, 2012, s.42). Yazarların yorumlarından görüleceği üzere erkeğin sahip olması gerektiği "ideal beden" bakıml,, temiz, iyi giyimli, atletik ve kaslı olma üzerinden tanımlanmasının yanı sıra, bir iktidar unsuru olan sınıfsal konumun bu imajda etkili olduğu sıklıkla vurgulanmıştır.

"Paraya göre şekillenen akışsan. "(Dolma bahçe)

İdeal bir bedenin bireylerin sahip oldukları maddi imkanlar ile doğru orantılı olduğunu belirten bazı yazarlar, toplumda erkekler arasındaki sınıfsal farklılıkların da "ideal beden"ne sahip olma önündeki en büyük engel olduğunu belirtmektedirler. Așağıda seffaffrench kullanıcı adlı yazar tarafından "ne yersen öyle gözükürsün" ifadesi aslında sınıfsal konum ile beden arasındaki ilişkiyi en net ortaya koyan ifadelerden biridir: 
"ben ve çevremdekiler estetik vücut oranlarına sahibiz ama gözlemlerime göre yaşı ilerlemiş olanlar birden yağlanıyor genç ve zayıf olanlar da zeytin yutmuş kürdan gibi duruyor, ayıplamamak lazım imkan meselesi bu ne yersen öyle gözükürsün et fiyatları ortada yeterli proteini alamayıp yüksek kalorisi olan ve basit karbonhidrat içeren besinlerle beslenmenin bir sonucu bu görüntüler."(seffaffrench)

Bluesstick kullanıcı adlı kişinin yorumlarına bakıldığında da yine aynı doğrultuda evini geçindiren erkeğin sorumluluklarının ve geçim derdinin ön planda olmasının Türk erkek bedeninin eleştirilmesine bir tepki niteliğinde olduğu görülmektedir:

\begin{abstract}
"Fitness sektörü içinden biri olarak , ...göbekli diye yaftaladığınız çoğu adam geçim derdinde . en uсuza ailemi nasıl doyururum diye düşünmekten insanlar kilo allyor maalesef. bunun ucuz ve sağlıklı versiyonu yok mu tabi ki var , o noktada kültürel beslenme alışkanlıkları devreye giriyor. basit hesap ile 3 kişilik bir aile protein, karbonhidrat ve yağ besinlerinin dengeli hazırlandığı bir öğünü 30 tl’ye halledebilirken . bir paket makarna 3 tl , bu daha cazip geliyor." (bluesstick)
\end{abstract}

Erkeklerin maddi imkanlara sahip olmasının yanı sıra, bu sınıfsal farklılığı belirleyen bir başka unsur "şehirli" olmasıdır. Tüketim kültürü ile şekillenen "ideal beden" algısında kırkent ayrımı önem taşımaktadır. Postfordist üretim tarzı ile birlikte tüketim alışkanlıkları değişen şehirli orta sınıf için "tüketim" yaşam tarzlarının ve kimliklerinin bir parçası haline gelmiştir. Bu sembolik tüketim eğilimi içerisinde bakımlı olmak (tırnak, saç, vücut bakımı, parfüm gibi kozmetik ürünleri kullanma vb.), spor yapmak (düzenli gidilmese dahi genellikle bir spor salonuna üye olmak) ve iyi giyinmek gibi edimler bulunmaktadır. Aşağıdaki Ekşi Sözlük yazarının yorumuna bakıldığında orta sınıf şehirli erkek imajının, kadınlar ve diğer erkekler üzerinde kurduğu hegemonik idealin izleri görülmektedir:

“şehirli erkeklerin kadınlara fark atacağı vücut. zira spor salonundakilerin \%95'i erkek. ... terden ıslanana kadar çalışıyorlar." ( eindaclub)

Anthony Gramsci'nin sınıf analizinden devşirilen "hegemonya" kavramından yola çıkan Connell'a göre, daima bir erkeklik biçimi kültürel olarak diğerlerinden öne çıkar. Hegemonik erkeklik toplumda erkeklerin baskın, kadınların ise madun konumda kalmalarını garanti altına alır (Connell, 2019, s. 150-151). Toplumsal cinsiyet ve sınıfın kesişiminde ortaya çıkan "ideal beden" algısının arkasında yatan orta sınıf değerleri toplumsal güç ilişkilerini yeniden dönüștürmektedir:
"spor alışkanlığımız olmamasından, sağlıklı beslenemememizden/beslenmememizden, iş/işsizlik stresinden ötürü genelde yağlıdır. zayıf olsak bile göbekte o yağ bir miktar mevcuttur. tanımı erkekler özeline de indirmek çok yanlıştır. şu an tatildeyim, sabah plajdaydım. öyle iyi bir vücuda sahip insanoğlu göremedim."( turkcekarakterlinikimolsaydikeske)

Beden ve erkeklik arasındaki ilişkiyi inceleyen araștırmacılardan biri olan Connell'a göre erkeklik beden ile ilişkilidir. Kültürel olarak en değerli kılınan erkek bedeni hegemonik erkekliğin sürekliliğin sağlanmasında ve sürdürülmesinde önemli bir belirleyicidir (Öztürk, 2012, s.45). Ekş̧i Sözlük’te “Türk erkeği vücudu” başlığı altında yapılan yorumlarda görüldüğü üzere "ideal beden" algısı toplumsal cinsiyetin sembolik düzeni içerisinde sinıfsal faktörler ile birlikte değerlendirildiğinde hiyerarşik bir yapılanmayı yeniden ürettiği söylenebilir. İdeal erkek bedenini kaslı, atletik, bakımlı olmak üzerinden tanımlayan söylemler şehirli, orta ve üst seviyede gelir düzeyine sahip erkeklik normlarına sembolik bir güç atfetmektedir. Öyle ki genellikle spor yapmadığı ve bakımlı olmaması sebebiyle eleştirilen Türk erkeği için "ideal bedene" sahip olmak, belirli bir gelir ve refah seviyesini gerekli kılmaktadır. Günümüz şartlarında bir salonuna üye olmak, kişisel kozmetik bakım ürünlerini kullanmak ortalama gelir düzeyine sahip erkek 
bireylerin çoğunluğu için temel ihtiyaçlarının ötesinde bir lükstür. Toplumsal olarak inşa edilen "ideal erkeklik" tanımı hem kadınların "kadınsılık"larını hem de diğer erkeklerin "erkeksilik"lerini ölçmek için bir araçtır. Dolayısıyla "beden" üzerinden üretilen söylemlerin hem toplumsal cinsiyetin hem de sınıfsal yapının sembolik düzenini yeniden üreten bir işlevi olduğunu söyleyebiliriz. İdeolojilerin yarattığı eşitsizlikleri söylem üzerinden açığa çıkarmak üzerine temellenen söylem analizi yöntemi, hem toplumsal cinsiyet ayrımcılığı ideolojisini dair eşitsizlikleri hem de sınıf ideolojisinin zenginler ve fakirler arasındaki eşitsizlikleri ortaya çıkarmayı mümkün kılmıştır.

\section{Ekşi Sözlük’te “Türk Kızı Vücudu” Başlığı Altında Yapılan Yorumların Analizi}

İdeal kadın bedenine yönelik algılar tarihsel süreç boyunca toplumların kültürel bağlamları odağında sürekli değişime uğramıștır. Örneğin, Türkiye bağlamında bakıldığında bundan 50-60 yıl öncesine kadar balıketli olarak tabir edilen hafif kilolu kadın imgesi güzel olarak kabul edilirken, günümüzde zayıf, ince ve narin bir beden yapısına sahip kadın imajı güzel olarak kabul edilmektedir. Günümüzde içinde bulunduğumuz tarihsel ve kültürel bağlamda ise "ideal kadın" bedeni, tüketim kültürünün, medya ve popüler kültür endüstrisinin etkisiyle dönüşüme uğramıștır. Zayıf, ince, bakımlı, spor yapan ve fit bir görünüme sahip olan kadın imgesi tüketim odaklı bir beden anlayışını ortaya çıkarmıștır ve birer mit durumuna gelmiștir.

\section{İdealleştirilen Beden Üzerinden Gelenekselliğin Suçlanması: "Kezbanlık”}

Kızılçelik (2003) küreselleşme adı altına gizlenen kapitalizmin sürekli kar arayışının insanının emeğinin sömürülmesine, kendisine, yaşadığı topluma, fiziksel olarak çöküntüye uğratılmasına ve bedenin bozulmasına neden olduğunu belirtir. Bunun sonucu olarak ise çağdaş toplumlarda bedeni bir "proje alanı" haline getiren inanç, uygulama ve normlar işlevsel hale gelmiş, bireylerin ise şizofrenler gibi gerçeği fark etmesi engellenmiștir (Kızılçelik, 2003, s. 90-91). Küresel medyanın başını çektiği tüketim endüstrisi tarafından sanal olarak idealize edilen ve gerçek(miş) gibi algılanan bedenler gelenekselliğe saldırı noktasına gelmiştir. Ekşi Sözlük'te Türk kızı vücudu ile ilgili yapılan yorumlar olumsuz eleştirilerin ötesinde aşağılayıcı bir boyuttadır:

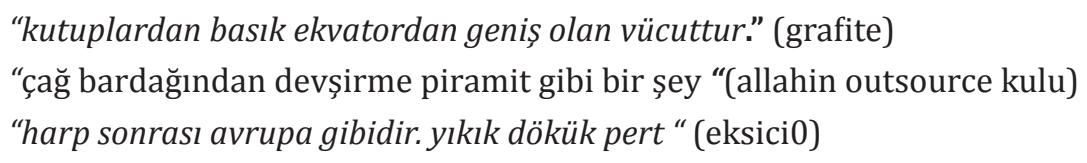

Ataerkil toplumsal yapının kendini tüketim üzerinden yeniden ürettiği günümüzde kadın bedeni giyimi, bedensel pratikleri, güzellik mitinin dayattığı estetiksel algılar temelinde yeniden kontrol altına alınmıştır. Bu doğrultuda aşağıdaki ifadelerde de görüleceği üzere kadının ne giymesi, nasıl bir ten rengine sahip olması, nasıl makyaj yapması gerektiği kontrol altına alınmaya çalışıldığının bir göstergesidir:

\footnotetext{
"gen havuzu kötü, spor yok, diyet yok, bronzlaşmayı bilmez, epilasyon etek boyuna kadar, makyaj bilmez, yakıștı mı düşünmeden babet giyer, yolda yürüyebiliyor muyum demez stiletto giyer. entellektüel zeka seviyesi facebooktan instagramdan kaptıkları. ülkemin yaşam standardını da ekleyince sonuç şaşırtıcı değil. bu eziyeti adriana lima'ya yapın tüküren lamaya dönmezse gelin beni bulun. not: yukarıdaki tanımın dışında olanları isa korusun. hatta siz de koruyun lan soyu tükenmesin lazım olur." (sen yoksun ya yeter)
}

Ekşi Sözlük yazarları tarafından “Türk kızı vücudu” ilgili yapılan yorumlara bakıldığında, genel bir eğilim olarak söylemlerde kadınların "geleneksellik" ile ilişkilendirilerek küçümsendiği görülmüştür. Spor yapmama bașta olmak üzere hareketsiz yaşam, beslenme 
tarzı, giyim vb. sebepler "Türk kızı vücudu”nun “ideal beden" algısına uymamasının gerekçeleri olarak öne sürülmektedir ve "öteki” ile kıyaslanarak eleştirilmektedir:

“dünya üzerinde spor yapmayan her kadının vücudu kötüdür. sporyapmamak türk kızı geleneğine dönüşmüştür ne yazık ki. tabi kız başlarına spor yapacak değillerdi “( a very composite material)

"derseniz elin kızı niye taş gibi; beslenme ve yaşam tarzı. daha çok hareketliler ve spor yapıyorlar ve yemek kültürleri gelişmediği için pek yağ almıyorlar. 12 yaşındaki ispanyol kız bile sabah evdekiler uyurken koşusunu yapıp evde duşunu alıp sofrasını hazırlıyor. yani özellikle sporu yaşam tarzı yapmışlar." (alpican6161)

"spor yapın kızlar benden size demesi sonra yaş 30'u geçince firından çıkmış somun ekmek gibi olursunuz bir de çocuk doğurduğunuz zaman susamlı ramazan pidesine dönersiniz "(turkiyeden bikan pilot)

"Kezbanlık" genel olarak yorumlarda geleneksellik ile ilişkilendirilen bir hakaret biçimi olarak sıklıkla köylülüğü, kırsallığı işaret eden bir isim ya da sıfat olarak Türk kızı bedenini nitelerken kullanılmaktadır:

"başlığı görünce bile gülümsedim...birden genişleyen basen, kalın bir bel, dar üst beden. gel gör ki bu kız kendini miranda kerr sanır. güzel kadının kaprisleri olduğunu kapris yaparsa güzel kadın olacağını sanır ama bu onu sadece kezban yapar..." (yagmurluhavadasusatanadam)

“öncelikle bu başlıkta bile kezbanlık yapan bayanlarımızı kutluyorum.uzun zamandır spor yapan biri olarak spor salonlarında erkeklerin kadınlara olan fazlalığından bahsetmeye gerek yok sanırım herkes biliyordur ve kadınlar maksimum 2 ay devam ediyorlar erkekler bu konuda daha uzun vadeli spor yapıyorlar.vücudunuzdaki dengesizlikleri görüp harekete geçmemek sizin hatanızdır.istediğiniz taktirde gayet güzel bir vücudunuz olabilir. "(türkiyeden bikan pilot)

\section{Sınıf ve Toplumsal Cinsiyetin Kesişiminde Kadın Olma Hali}

Kadınlık eğitim, yaș, etnisite, sınıf gibi değişkenlere göre farklılık gösteren homojen bir bakış açısından ziyade farklılıkları temelinde ele alınması gereken bir toplumsal kategoridir. Dolayısıyla "idealleştirilen kadın bedeni algısı" karşısında bu heterojen kategorideki farklı "kadınlık"ların, bu idealden sapma durumları çerçevesinde ele alınması gerekmektedir. Tüketim odaklı ideal kadın bedeni algısı, farklı sınıfsal kategorideki kadınlar üzerinde farklı tahakküm mekanizması işletmektedir. Nitekim literatürde yapılan çalışmalara bakıldığında ise tüketim odaklı ideal kadın bedeni algısının kadınlar üzerinde yarattığı baskıyı ortaya koyan birçok çalışma mevcuttur (Dedeoğlu \& Savaşçı, 2005; Doğan, 2010). Ekşi Sözlük'te "Türk kızı vücudu” ile ilgili yapılan yorumlarda sınıfsal farklılıkların ideal bedenden sapma nedeni olarak sıklıkla öne sürülmektedir:

\footnotetext{
"kendi sosyo ekonomik düzeyinize göre değişecek vücuttur." (seryer)

"sanırım ekonomik durumla ilgili ama genelde bakımsızlar" (eagle06)

"yukarıda tanımlandı̆̆ı şekillerde olmasının tek sebebi, türk yemek kültürünün maalesef ekmek, hamurişi, pilav gibi karbonhidratlar olmadan doyulmadığı zannedilen bir kültür olmasıdır. şöyle ki türkiyeden biraz çıktığınızda ya da en basit exchange ya da avrupai yaşayan zengin çevreyi incelediğinizde çözersiniz. bunlarda ekmek pilav denen şeye en ufak bir eğilim yoktur, yemekleri hep sulu yemek salata yoğurt içerir, bol su içerler ve de daha çocukluklarından itibaren sporla haşır neşirlerdir. misal koç üniversitesi elit(!) kızlarını incelediğinizde çoğu inanılmaz uzun boylu ve incedir (ki bu bunların küçüklükten beri protein süt vs ile beslenmesinin ve tenis bale yüzme gibi sporların büyük katkıs vardır) ve yemek yeme alışkanlıkları hep salata,sebze üzerine kuruludur. bir de bunların tatlı yerine meyveli yoğurt tüketimi vardır ki konuya son noktayı koyar zannediyorum. tanım: genlere işlemiş̧ kültürün yamulttuğu kız vücududur yine de bu tembelliğe alışmayı haklı göstermez." (hainelf)
} 
“ithal mama ile büyüyüp büyümediğine göre ve spor yapıp yapmadiğına göre değissen vücut çeşididir. 88 öncesi ve sonrasında ilginç bir ayrım bulunmaktadır."( los angeles los angeles)

"bu tip serzenişte bulunanların yaş ortalamasını tahmin edebiliyorum. tam bir ergen kafası. halk plajına gittiği de ortada. girişine yüzlerce tl vereceğin ünlü beachlere git bakalım. görürsün belki istediklerini.." (kirli yesil kazak)

Kadını ev içinde tanımlayan ataerkil toplumsal yapıda ev ve ev işleri her ne kadar sınıf, statü, kuşak ve eğitim düzeyine göre farklılașsa da kadın öznelliği tanımlayan önemli yapıtaşıdır (Alyakurt, 2016, s.698). Kadının toplumsal rolünü ev işleri, çocuk bakımı ile tanımlayan kültürel pratikler, namus olgusunun kadının bedenini, giyimini ve hareket alanını sınırlaması gibi kültürel engeller günümüzde idealleștirilen kadın imgesinin önündeki engeller olarak söylemlerde yine sıklıkla yer bulmaktadır.

\begin{abstract}
"spor salonlarında erkeklerin fazlalığından bahsedenler buranın Türkiye olduğunu unutmuş dicem ama Türk kadınından bahsettiğine göre unutmamıştır heralde. burası Türkiye yani Türk kadını işten çıkınca evde yapacağı bir sürü iş vardır, bakacağı çocuk vardır ve spora vakit ayıramaz. ama ona asla yardım etmeyen kocası spor salonuna gidebilir. burası Türkiye yani Türk kadını spor salonuna gitmeye çekinir, gitse de rahat giyinemeyebilir Çünkü Türk erkeği tacize bayılır burası Türkiye yani Türk kadını akșam isten sonra spora giderse de dönüş yolunda hele de vakit geçse ve evi tenha bir yerdeyse başına her şey gelebilir. sporu bir kenara at eğer hayatta kalıyorsa Türk kadını haline şükreder durur!" (portakalsoslukek)

"cinsiyetten bağımsız olarak haklılık payı yüksek ama. kadını erkeği pek de formda değil bizim insanımız. maalesef açık gerçek bu. kötü, yetersiz beslenme, spor düşmanı bir kültürel iklim yüzünden büyüme çağında her iki cinsin ama özellikle kadınların spordan uzak tutulması ve bu ortamı besleyip, insanlara yetişkinliğinde bile egzersiz yapacak zaman dahi bırakmayan kuralsız, vahşi sermaye düzeni asıl sebebi naçizane." ( neil mccauley)
\end{abstract}

Geleneksellik ilişkilendirilen ideal Türk kadını bedenine yönelik eleştirilerin karşısında yapılan yorumlara bakıldığında ise Türk kadının yalnızca bedenini düşünmek yerine kendilerine biçilen toplumsal cinsiyet rollerini (ev işi, yemek yapma, çocuk bakımı gibi) layıkıyla yerine getiren ve doğurgan kodlara sahip olan kadınlar olarak "öteki" kadınlar karşısında yüceltildiği görülmektedir:

\footnotetext{
"tamamen insanoğlunun dayatmasıyla olan eleştiridir.zamanında zayıf olan kadınlar beğenilmezdi hatta bu beğenmeyenlerin başında yine kadınlar gelirdi (hamamda gelin seçme) gel gelelim bu da kılık kıyafette olduğu gibi modadır.vakti zamanında balık etli hatun modayken şimdi tutturulmuş sıfır beden... beyler eğri oturup doğru konuşalım o spor yapan kızların çoğu yemek yapmasını bilmeyen sadece kendini düşünüp yeşillikle beslenen kızlar. bırakın balık etli kızlarımız olsun bizi onlar düşünür onlar besler,çocuğumuzun anası olabilecek analık bilincini taşıyanlar yine onlar olur.övünmeyi bilin kızlarımız candır ! ağzımızın suyunu akıtarak baktı̆̆ımız slavların çoğu daha 30 u görmeden iğrenç bi vücut yapısına bürünüyorlar. "( sanaticinsanat)

"göbek veya karın kısmı genişşedir. çünkü türk kızı doğurgan kodlara sahiptir." (karabetgulludere)
}

Görüldüğü gibi "ideal beden algısı" üzerinden farklı "kadınlık"lar kendi içerisinde hiyerarşik bir sıralanmaya tabi tutulmaktadır. Bir yandan tüketim kültürünün dayattığl ideal kadın imgesine sahip olmak gelenekselliğin reddi ile mümkün kılınmaya çalışılırken, buna karşılık geleneksel toplumsal cinsiyet rollerinin vurgulanarak Türk kadının yüceltilmesi söz konusudur. Ancak her halükarda eril tahakküm, sosyal tahakküm ilişkilerini bedenselleştirerek iktidarını pekiştirmektedir. 


\section{Sonuç}

1980'lerden itibaren kapitalizmin bireyler için değiştirilip, dönüştürülen, şekil verilen bir meta olarak bedene yönelmesine ve nihayetinde bedenin kimliğin bir parçası haline geldiğine tanık olmaktayız. Günümüzde sosyal medya başta olmak üzere, gazeteler, dergiler, reklamlar, filmler gibi popüler kültür ürünleri vasıtasıyla kitlelere pompalanan "mükemmel" ve "ideal" beden algısı kitleleri tüketime mobilize etmektedir. Sosyolojik açıdan toplumsal yapıda idealize edilen beden algısının sınıf ve toplumsal cinsiyet gibi eșitsizlik yaratan kategoriler bağlamında bakıldığında derin yarılmalar yarattığı gözlemlenmektedir.

Kitle iletişim araçları cinsiyetçi ideolojileri ve kapitalist üretim ilişkilerinin yarattığı eşitsiz ideolojileri kitlelere söylemler yolu ile yaymaktadır. Geleneksel sözlük anlayışından farklı olarak, bireylerin özgürce bir durum, olay, olgu ve kişi hakkında yorum yapabilmesine olanak tanıyan ve yeni kamusallık olarak adlandırılan "Ekşi Sözlük", bu çalışmanın kapsamını oluşturmaktadır. Gerçek kimliklerini gizleyen yazarların yorumlarıyla sürekli güncellenen platform, en çok rağbet gören sitelerden biri olma özelliğini taşımakta, kendine ait bir alt kültür oluşturması açısından da bu çalışmanın kapsamını belirlemektedir. Çünkü alternatif bir kamusal olarak nitelenen Ekşi Sözlük söylemlerin en açık bir şekilde izlenebileceği sosyal platformlardan birisidir.

Söylemin güç/iktidar ve ideoloji üzerine temellendiği temel varsayımından hareketle yapılan bu çalışmada, Ekş̧i Sözlük'te toplumsal cinsiyet ve bedene yönelik algıları ortaya koyabilmeye olanak sağlayacak 6 başlık tespit edilmiştir. Bu başlıklardan iki tanesi olan "Türk kızı vücudu" ve "Türk erkeği vücudu" başlıkları amaçlı örneklem tekniği kullanılarak seçilmiştir. "Türk erkeği vücudu" başlığı altına yapılan 240, "Türk kızı vücudu” başlığı altına yapılan 1080 yorum, eleştirel söylem analizi yöntemiyle değerlendirilmiștir. Van Dijk'in Eleștirel Söylem analizi yönteminin tercih edildiği çalışmada veriler; toplumsal cinsiyet, beden ve iktidar olgusunun birlikte yarattığı hegemonya çerçevesinde incelenmiştir.

Dilde örtülü şekilde bulunan söylemler, toplumdaki güç ilişkilerini gündelik yaşamda yeniden üretmektedir. Sınıf ve toplumsal cinsiyet gibi güç ilişkilerini belirleyen ideolojiler söylemleri şekillendirmektedir ve bu açıdan Eleştirel Söylem Analizi yöntemi güç ilişkilerinin yarattığı toplumsal hiyerarşileri ortaya çıkarmakta bu çalışma açısından analitik bir perspektif sağlamıştır. Öyle ki söylem analizi yöntemi bu çalışma çerçevesinde, toplumsal cinsiyet ve bedene ilişkin söylemlerin örtülü bir biçimde sınıfsal eşitsizlikleri de dilde taşıdığını ortaya koymada ne kadar önemli bir yöntem olduğunu bir kez daha göstermiștir.

Sınıf ve toplumsal cinsiyet gibi değişkenler ile birlikte incelenen beden olgusunun sembolik bir önem taşımaktadır (Öztürk, 2012, s.39). Sembolik bir önem taşıyan beden olgusu literatürde sınıf ve toplumsal cinsiyet gibi sosyal değișkenlerin oluşturduğu simgesel güç ve hiyerarşi bağlamında ele alınmaktadır (Bourdieu, 2018; Goldenberg, 2010; Köse, 2011; Öztürk, 2012).

İdealize edilen bedenler ve giydirilen imajlar, farklı "kadınlık" ve "erkeklik" anlayışlarını ortaya çıkarmaktadır. İdealize edilen "kadın”lık ve "erkek"lik durumları, Bourdieu'cu perspektiften bakıldığında eril tahakkümün işlevselliğini pekiştirmektedir. Yapılan analizlerde de ortaya konulduğu üzere "idealize" edilen hegemonik erkek bedeni diğer erkek ve kadın bedenlerini kategorize etmekte bir ölçüt haline gelmektedir. Bir iktidar alanı olarak beden, biyolojik varlığının ötesinde bir sosyal inşadır. Bedene yönelik 
söylemelere bakıldığında sınıf ve eril iktidarın gücüne dayalı olarak inşa edildiği ve ideolojik bir yönünün olduğu görülmektedir. Orta ve üst sınıf (profesyonel, şehirli, beyaz yakalı) erkekliğin ve bunun göstergesi olan kaslı,fit, sağlıklı, marka giyimli, bakımlı erkek bedeninin birçok çalışmada (Barber, 2008; Dhareshwar\&Niranjana, 1996) da vurgulandığı üzere hegemonik erkekliğin bir kurucu unsuru olduğu söylenebilir.

Özellikle tüketim endüstrisi ve küreselleşme ile birlikte idealize edilen beden algısı yerleşik geleneksel değerleri ve tutumları aşındırmakta, hatta araştırmanın analiz sonuçlarından da görüldüğü üzere, çoğu zaman cinsiyetlendirilmiş bir biçimde gelenekselliği saldırı noktasına gelebilmektedir. Tüketim endütrisinin dayattığı idealize edilmiş "beden" e ulaşmak ise belirli bir ekonomik sermayeyi gerekli kılmakta, bu durumda da sinıfsal bir hiyerarşi de söylemlerde yeniden üretilmektedir (Goldenberg, 2010). Bu bağlamda genel olarak değerlendirildiğinde; sınıf ve toplumsal cinsiyet ideolojilerinin idealize edilen beden üzerinden söylemlerde yeniden üretildiği söylenebilir. Hegemonik erkeklik ideal beden algısı üzerinden toplumda bir iktidar konumu olan sınıfsal değişkenler üzerinden yeniden üretilmektedir. Eril iktidarın yarattığı söylemler, kadın bedenini ise geleneksellik ile ilişkilendirerek küçümsemekte ve tahakkümünü yine hem beden hem de geleneksel toplumsal cinsiyet rolleri üzerinden yeniden kurmaktadır.

$\mathrm{Bu}$ çalışma, toplumda eşitsizlik yaratan iki kategori olan toplumsal cinsiyet ve sınıfın yarattığı ideolojileri günümüzde yaratılan "ideal beden" algısı üzerinden incelemektedir. Ancak toplumda eşitsizlik yaratan diğer kategoriler olan engellik, göçmenlik, etnisite, cinsel tercih, yaş vd. bağlamında daha ayrıntılı bir şekilde incelenmesi gerekmektedir. Bu doğrultuda toplumdaki iktidar ilişkileri ve bu ilişkilere temel olan ideolojilerin ortaya çıkardığı söylemlerin, özellikle söylem analizi yöntemiyle ileride yapılacak akademik çalışmalarda derinlemesine bir şekilde analiz edilmesi ihtiyacı bulunmaktadır.

\section{Kaynakça}

Alp, H. (2016). Çingenelere Yönelik Nefret Söyleminin Ekşi Sözlük'te Yeniden Üretilmesi. Ankara Üniversitesi ILLEF Dergisi, 3(2), 143-172.

Alyakurt, Ö. (2016). Postmodern Toplumda Kadın Kimliğinin Bedeni Üzerinden İnşası Journal of International Social Research, 9(47), 696-708.

Barber, K. (2008). The Well-Coiffed Man: Class, Race, and Heterosexual Masculinity in the Hair Salon. Gender \& Society, 22(4), 455-476.

Baş, T., \& Akturan, U. (2013). Nitel Araştırma Yöntemleri: Nvivo 7.0 ile Nitel Veri Analizi. Ankara: Seçkin Yayıncılık.

Baştürk Akça, E., \& Tönel, E. (2011). Erkek(lik) Çalışmalarına Teorik Bir Çerçeve: Feminist Çalışmalardan Hegemonik Erkekliğe. İ. Erdoğan (Ed.), Medyada Hegemonik Erkek(lik) ve Temsil içinde (s. 11-41). İstanbul: Kalkedon Yayınları

Bayraktar, L. (2010). Bergson'da Ruh-Beden İlişskisi. İstanbul: Dergah Yayınları.

Bourdieu, P. (2018). Eril Tahaküm (B. Yılmaz, Çev.). istanbul: Bağlam Yayıncılık.

Cirhinlioğlu, Z., \& Cirhinlioğlu, F. G. (2011). Postmodern sağlığın Yükselişi ve Düşüşü. K. Canatan (Ed.), Beden Sosyolojisi içinde (s. 395-413). İstanbul: Açllım Kitap.

Connell, R. W. (1998). Toplumsal Cinsiyet ve İktidar: Toplum, Kişi ve Cinsel Politika (C. Soydemir, Çev.). İstanbul: Ayrıntı Yayınları.

Connell, R. W. (2019). Erkeklikler (N. Konukçu, Çev.). Ankara: Phoenix. 
Connolly, W. E. (1995). Kimlik ve Farklılık: Siyasetin Açmazlarına Dair Demokratik Çözüm Önerileri. İstanbul: Ayrıntı Yayınları.

Çelik, H., \& Halil, E. (2008). Söylem analizi. Marmara Üniversitesi Atatürk Eğitim Fakültesi Eğitim Bilimleri Dergisi, 27(27), 99-117.

Çomu, T., \& Halaiqa, İ. (2015). Web İçeriklerinin Metin Temelli Çözümlemesi. M. Binark (Ed.), Yeni Medya Çalışmalarında Araştırma Yöntem ve Teknikleri içinde (s.). İstanbul: Ayrintı Yayınları.

Dedeoğlu, A. Ö., \& Savașçı, İ. (2005). Tüketim Kültüründe Beden Güzelliği ve Yemek Yeme Arzuları: Kadınların Tüketim Pratiklerine Yansıması Ege Akademik Bakış Dergisi, 5(1), 77-87.

Demez, G. (2011). Sanal Dünyanın Kișisel Alanı: Bir Sosyal Paylaşım Ağı Olarak Facebook'ta Erkek(lik) Tartışmaları. İ. Erdoğan (Ed.), Medyada Hegemonik Erkek(lik) ve Temsil içinde (s. 325-353). İstanbul: Kalkedon Yayınları.

Dhareshwar, V., \& Niranjana, T. (1996). Kaadalan and The Politics of Resignification: Fashion, Violence and The Body. Journal of Arts and Ideas(29), 5-26.

Doğan, S. Y. (2010). Tüketim Kültüründe Kadın Bedeninin İdealize Edilmesine Yönelik Kadın Algılamaları ve Tüketim Davranışlarıyla İlişkisi. Selçuk Üniversitesi Sosyal Bilimler Enstitüsü Dergisi(23), 51-59.

Erdoğan, İ. (2013). Erkek Dergilerinde Sağlıklı Erkek Neden İdeal Erkektir? Men’s Health Dergisi'nde Hegemonik Erkeklik ve Popüler Sağlık Söylemi. Galatasaray Üniversitesi İletişim Fakültesi Dergisi İleti-ş-im (Sağlık İletişimi Özel Sayısı), 3, 133-154.

Erdoğan, İ. (2014). Medya ve Teori Araştırmaları. Ankara: Erk Yayınları.

Ertan, C. (2011). Medyada Eşcinselliğe ve Eşcinsellere İlişkin Söylem(ler): Televizyon Dizisi “Bir Kadın Bir Erkek" ve (Hegemonik) Erkek(lik) Temsili. İ. Erdoğan (Ed.), Medyada Hegemonik Erkek(lik) ve Temsil içinde (s. 95-125). İstanbul: Kalkedon Yayınları.

Goldenberg, M. (2010). The Body as Capital. Understanding Brazilian Culture. VIBRANTVibrant Virtual Brazilian Anthropology, 7(1), 220-238.

Gülkaya Timurturkan, M. (2008). Felsefi Bedenden Sosyolojik Bedene. Ethos, 1(4), 1-14.

Gürel, E., \& Yakın, M. (2007). Ekşi Sözlük: Postmodern Elektronik Kültür. Selçuk Üniversitesi İletişim Fakültesi Akademik Dergisi, 4(4), 203-219.

Hacısoftaoğlu, İ., \& Koca, C. (2011). Spor Medyasında Hegemonik Erkekliğin (Yeniden) Üretimi: Delikanlı Gibi Yaşayın, Delikanlı Gibi Oynayın. İ. Erdoğan (Ed.), Medyada Hegemonik Erkek(lik) ve Temsil içinde (s. 69-95). İstanbul: Kalkedon Yayınları.

Kaplan, M. (2017). Bourdieu Düşüncesinde Eril Tahakküm ve Beden Nosyonu. Journal of Social and Humanities Sciences Research, 4(15), 1831-1836.

Kara, Z. (2011). Beden Sosyolojisinden Ölüm Sosyolojisine Beden Sosyolojisi içinde (s. 2345). İstanbul: Açılım Kitap.

Karaduman, S. (2017). Eleștirel Söylem Çözümlemesinin Eleştirel Haber Araştırmalarına Katkısı ve Sunduğu Perspektif. Maltepe Üniversitesi İletişim Fakültesi Dergisi, 4(2), 31-46. 
Kızılçelik, S. (2003). Küreselleşme Beden ve Şizofreni. CÜ Tıp Fakültesi Dergisi, 25(4), 8994.

Köse, H. (2011). Tüketim Toplumunda Bir “Sosyal Beden” Kurgusu Olarak Kadın. 6(4), 7689.

Köse, H. (2016). Bourdieu Düşüncesinde Tahakküm-İtaat İlişkisi ve Sosyo-Politik Beden. Ankara Üniversitesi ILLEF Dergisi, 3(2), 173-199.

Krais, B. (2006). Gender, Sociological Theory and Bourdieu's Sociology of Practice. Theory, Culture \& Society, 23(6), 119-134.

Kula Demir, N. (2016). Erkek Dergilerindeki Reklam Fotoğraflarında (Yeniden) Üretilen Metroseksüel Kimlik. H. Kuruoğlu (Ed.), Erkek Kimliğinin Değişemeyen Halleri içinde (s. 81-105). İstanbul: Nobel Yaşam Yayınları.

Mora, N. (2008). İktidar ve Haber. N. Mora (Ed.), Medya Çalışmaları: Medya Pedagojisi ve Küresel İletişim içinde (s. 4-30): Alt Kitap.

Nazlı, A. (2006). Bedenin Ölümü: Modern Öncesinden Postmoderne Beden ve Ölüm. Sosyoloji dergisi(16), 1-15.

Oğuz, M. C. (2008). Söylem Analizi. Sosyoloji Notları, 5, 52-58.

Öztürk, A. (2012). Eril Bedenselleşme: Hegemonik Erkek Bedeninin İnşaası. Felsefe ve Sosyal Bilimler Dergisi, 13, 39-53.

Seden Meral, P. (2011). Erkek Hegemonyasının (Yeniden) Üretimi: Dergi Reklamlarında Hegemonik Erkekliğin Temsili. E. İlker (Ed.), Medyada Hegemonik Erkeklik ve Temsil içinde (s. 297-323). İstanbul: Kalkedon Yayınları.

Talimciler, A. (2016). Türkiye'de Erkek Kimliğinin Oluşumunda Göz Ardı Edilen Alan: Spor/Futbol. H. Kuruoğlu (Ed.), Erkek Kimliğinin Değişemeyen Halleri içinde (s. 4367). İstanbul: Nobel Yaşam Yayınları.

Turner, B. S. (1992). Regulating Bodies: Essays in Medical Sociology. London: Routledge.

Ülkü, G. (2004). Söylem Çözümlemesinde Yöntem Sorunu ve Van Dijk Yöntemi. Ç. Dursun (Ed.), Haber Hakikat ve İktidar İlişkisi içinde (s.): Elips Kitap.

Van Dijk, T. A. (1993). Principles of Critical Discourse Analysis. Discourse \& society, 4(2), 249-283.

Van Dijk, T. A. (2015). Söylem ve İdeoloji: Çok Alanlı Bir Yaklaşım (B. Çoban, Çev.). B. Çoban \& Z. Özarslan (Eds.), Söylem ve İdeoloji içinde (s. 15-101). İstanbul: Su Yayınları.

Yazıcı, T. (2016). Yeni Medyanın Nefret Dili: Suriyeli Mültecilerle İlgili Ekși Sözlük Örneği. Global Media Journal TR Edition, 7(13), 115-136.

Yerlikaya, T. (2019). Critical Discourse Analaysis and Social Media: New Apporoaches in Critical Discourse Analysis Studies. Iğdır Üniversitesi Sosyal Bilimler Dergisi, 18, 193-209. 


\title{
Gender, Power and Body Analysis through Eksi Sozluk - The New Face of Public Space
}

\author{
Tuğba Metin Açer (Asst. Prof. Dr.)
}

\section{Extended Abstract}

The development of communication technologies has radically transformed all areas of social life. The traditional dictionary conception has also kept pace with this change and transformation, and the e-dictionary conception has gained quite popularity. It has become an important platform where crucial social issues, events, problems are presented and discussed by individuals. The e-dictionary, which is called "new publicity" in the literature, sustains its popularity as a conception that 'truth' does not have a single explanation and that there may be different perspectives, unlike the traditional dictionary. 'Eksi Sozluk', founded in 1999 as one of the pioneers of this approach, is currently among the most followed internet sites in Turkey. 'Eksi Sozluk', which has been in service since February 1999, can be defined as an interactive platform and database; containing information, experience, humor, comments, questionnaires, links and sources with regard to words, terms, concepts, and people (Gürel \& Yakın, 2007, s.203). 'Eksi Sozluk' has a prominent place in the context of postmodern electronic culture as its structure reveals that there is not a single explanation of truth and therefore proceeds based on spontaneous order (Gürel \& Yakın, 2007, s.203). Authors make comments (called entries) about an event, situation, or person under specific headings (opened by themselves or others) on the website. Therefore, Eksi Sozluk is an essential alternative platform where public power relations in the eyes of individuals can be read.

Another area of transformation arising from communication technologies and the consumption industry is "body" and "gender." In contemporary capitalist societies, the body is a prime field of consumption shaped by the consumption industry. Clean, wellgroomed and beautiful body perception that spread with globalization directly affects consumption (aesthetics, make-up, using beauty and care products) and spare time activities (trying to create ideal bodies in gyms). Additionally, magazines, newspapers, advertisements, films and series, especially social media, bring out new feminity and masculinity approaches by pumping the perfect body imagining to the masses. Male and female body perception differs depending on habitus within the symbolic order of gender in social life. The social construction of 'manhood' and 'womanhood' shapes the body, defines how it is perceived, steers habits, and thus determines the personal identity as masculine or feminine via the body (Krais, 2006, s.121). According to Bourdieu, male dominance is in fact the embodiment of the relations of social dominance within the symbolic gender order (Krais, 2006). The primary purpose of this study is to examine how the hegemonic discourses imposed on the idealized body perception imposed by the consumer industry are reproduced employing the media.

On the other hand, its another aim is to reveal the roles and pressures posed by the ideal body perception to men and women. The comments made about the body in the "Ekşi Sözlük" determine the scope of this research. There were six headings in the "Ekşi Sözlük," where gender perception of the body could be monitored, two of which were selected using the purposive sampling technique. In this study, the discussions and interpretations until March 2019 under the titles of the 'Turkish male body' and 'Turkish 
female body, both opened in 2013, were analyzed. Critical discourse analysis was used to evaluate 240 comments under the title of 'Turkish male body,' and 1080 comments under the title of 'Turkish female body.' During the data analysis phase of the study, comments were encoded and categorized in three stages using the qualitative data analysis program called Nvivo 8. At the end of the qualitative data analysis process, five themes were revealed and interpreted.

Gender ideology and discourses have been examined based on the assumption that discourse has an ideological aspect - by taking into consideration the social context of today's body perception. The discourse is highly substantial in the reproduction of ideologies and social, economic, political power relations. Van Dijk (2015, s.25), one of the pioneers of critical discourse analysis, explains ideologies as a constitution that creates the underlying social representations of beliefs shared by a group and precisely defines the overall coherence of these beliefs. Accordingly, Van Dijk analyzes ideological discourses within the framework of the positioning of social differences (such as ethnicity, gender, class.) in a vertical hierarchical structure (Karaduman, 2017, s.39). Critical discourse analysis has provided this study with an analytical perspective because it is a rational approach in analyzing discourses that are implicit in language but also reproduce the relationships of power and hierarchy in society.

As a result of the data obtained, it was found that the Turkish female body was neglected and deformed due to lack of doing sports, and therefore it was underestimated by being associated with 'traditionalism.' On the contrary, the male body was extolled because of being more well-groomed, fit and shaped than Turkish female body. Moreover, 'being like a woman' is associated with having perfect body measurements, while 'being like a man' means 'not being like a female body.' From a Bourdieusian perspective, male dominance reinforces its power by embodying social dominance relations; and the idealized 'hegemonic male body' becomes a criterion for categorizing other male and female bodies. Body is the carrier of the symbolic values examined according to categories such as race, class, ethnicity, gender (Öztürk, 2012, s.39). Various codifications, especially for gender groups, are useful in hierarchical regulation of gender order (Öztürk, 2012). This study gives clues on how male dominance, which is reproduced within the scope of the motto of ideal body perception, transforms individuals' gender and class habitus in 'Eksi Sozluk,' which provides a new public space for social debate. Hegemonic masculinity is reproduced through class variables which is a position of power in society in terms of the ideal body perception. The discourse created by masculine power belittles the female body by associating it with traditionality, and re-establishes its dominance over both the body and traditional gender roles. As a result, it can be said that male dominance, which emerges at the intersection of gender and class, positions different 'feminity' and 'masculinity' in terms of body in a hierarchical order within the hegemonic gender regime.

Keywords: Gender, Body, Power. 